\title{
Essential Oil Compositions of Subspecies of Scutellaria Brevibracteata Stapf from Turkey
}

\author{
M. ÇIÇEK ${ }^{1, *}$, G. YILMAZ ${ }^{2}$, B. DEMIRCI ${ }^{3}$, K.H.C. BAŞER ${ }^{3}$ \\ ${ }^{1}$ Pamukkale University, Turkey, 20070, Denizli, Department of Biology, Faculty of Arts and Science, \\ ${ }^{2}$ Ankara University, Turkey, 06100, Ankara, Faculty of Pharmacy, Department of Pharmaceutical Botany \\ ${ }^{3}$ Anadolu University, Turkey, 26470, Eskişehir, Faculty of Pharmacy, Department of Pharmacognosy
}

Key words: essential oil composition, Scutellaria, Lamiaceae, Turkey

Scutellaria L., with nearly 400 species, is one of the largest genera of the family Lamiaceae. In the last taxonomic treatment conducted by the first author, the genus Scutellaria has been evaluated as a genus with 33 taxa consisting of 25 species, 1 hybrid species and 13 subspecies in the Flora of Turkey. Turkish Scutellaria species are classified under three sections: section Scutellaria, section Salviifoliae and section Lupulinaria. We have here studied essential oil composition of the subspecies of $S$. brevibracteata belonging to the section Scutellaria. In the Anatolian traditional medicine, there is no more information on usage of Scutellaria except for the usage for constipation, hemostatic, tonic and wound healing, due to lack of its aromatic odour.

Dried the aerial parts of three subspecies of Scutellaria brevibracteata Stapf from Turkey were hydrodistilled. The chemical compositions of the essential oils obtained by hydrodistillation were analyzed by gas chromatography (GC) and gas chromatography/mass spectrometry (GC/MS), simultaneously. The subspecies of $S$. brevibracteata investigated here as follows: $S$. brevibractetata Stapf subsp. brevibracteata, S. brevibractetata Stapf subsp. subvelutina (Rech.f.) Greuter \& Burdet and S. brevibractetata Stapf subsp. pannosula (Rech.f.) Greuter \& Burdet.

According to the results of analyzing, $\beta$-caryophyllene $(22.8 \%)$ and caryophyllene oxide (16.0\%) were determined as the main components in S. brevibractetata subsp. brevibracteata oil. In $S$. brevibractetata subsp. subvelutina oil, $\beta$-caryophyllene (28.3\%), linalool (12.4\%), hexadecanoic acid $(10.8 \%)$ were found as major constituents. $\beta$-caryophyllene (36.4\%), a-cadinol $(9.8 \%)$, d-cadinene (7.0\%) linalool (5.3\%) were identified as major component in the oils of S. brevibractetata subsp. pannosula.

\footnotetext{
*Corresponding Author Phone: +90 258296 3881, Email: mcicek@pau.edu.tr This study was presented at $2^{\text {nd }}$ International Symposium Secondary Metabolites Chemistry, Biology and Biotechnology, 19-23 May 2014, Moscow
} 